\title{
The Concept of Money Laundering in Global Economy
}

\author{
Rădulescu Dragoş Lucian
}

\begin{abstract}
Underground economy is an expression that encompasses many conceptual terms, but irrespective of the existent definitions, it consists of certain activities that have persisted over time, especially illegal employment, tax fraud, illegal production, drug trafficking, smuggling, money laundering, etc. The influence of underground economy in the global context stands out due to cross-border activities, as well as due to the association with organized crime groups.
\end{abstract}

Index Terms-legal, international organizations, money laundering

\section{INTRODUCTION}

As a phenomenon parallel to the real economy, seen as mandatory in others, the underground economy is defined as invisible, occult, parallel, illegal, informal, etc. Previously denied because of its elements that are manifested almost chaotic, being difficult to study, it could not be ignored because the underground activities were manifested in the global economy.

But the reality of these events has exceeded the states' possibilities of control, because of the action area of the international criminal groups and the technological progress resulting from globalization. Crime groups have known better than some states to use the facilities in the globalized market, which prompted the international organizations to tailor their programs to various forms of underground global economy.

Accepted in some countries, fought against in the developed countries, underground economy is continuously evolving. Fraud, trafficking in arms and drugs, terrorism, corruption, money laundering are conducted by means of increasingly effective methods with a view to increase earnings. These gains have led the international crime organizations to abandon violent competition and to form occult alliances.

In general, it is noted that the activities of underground economy have known a true development, being stimulated by the phenomenon of globalization. Nations constantly lose elements of their sovereignty in the fight against organized groups, the latter showing that they know how to use legal loopholes, transferring amounts derived from illegal activities in countries that offer incentives. Regarding the political will of states to combat these phenomena it twas proved that some of them accept, tacitly, some forms of underground economy. In this regard, we consider not only developing countries or economies in transition, but even developed countries, maybe because of a willingness to obtain profit at any cost. In this sense, in countries like

Rădulescu Dragoş Lucian, Department of Law and Social Sciences, Petroleum-Gas University of Ploieşti, Ploiesti, Romania(email:dragosradulescu@hotmail.com).
Spain or Italy moonlighting is tolerated, and in the U.S. there is a dualistic concept linked to drug trafficking. Some authors argue that in the U.S., country ranked first in the world at drug consumption, there is no real desire for the total eradication of this phenomenon, only for keeping it to a convenient minimum. The motivation may be financial or political, referring to maintaining minimum income sources in countries of Latin America, which in the absence of such opportunities would become a problem in terms of immigration and crime.

Generally, this underground economy is seen as a niche for the poor as a way of accumulating illegal capital and as a true school for developing entrepreneurial capacities. It is assumed that the development of underground phenomena is due to weak institutional performance, as it was demonstrated that the informal sector is more developed as the country is poorer.

In transition states or in the former socialist states [2], the economy experienced a structural change, especially due to the opening of new markets, leading to an explosion in the phenomenon of corruption. The emergence of organized crime structures and the lack of legal regulations lead, in countries belonging to the former Soviet Union, like Russia, Georgia and Azerbaijan, to the largest underground economy. In the former communist bloc, Hungary and Bulgaria had the highest coruption rate, while the lowest was found in Slovakia and the Czech Republic.

Theoretically, the state socialist economy before 1989, due to shortage of products has caused a parallel underground economy, which has emerged as a parasite of the official one. State enterprises have combined their activity with that of the illegal underground enterprises. A research of the Institute for Quality of Life [17] shows that this parallel economy was determined by the survival attempts of the poorest stratum of the population, especially as the extreme poverty rate was two times higher in villages than in cities. Furthermore, it was determined that the richest fifth of the population in Romania owes its revenue to the underground economy activities.

Globally, in developing countries[1] the situation of this informal sector is absolutely different from that of the industrialized states. Transition[2] as a consequence of the collapse of communism in Central and Eastern European countries, accompanied by the loss of state authority, represents a crucial cause of the extent of the underground economy phenomenon.

This is characterized by subsistence economy in a large traditional sector where the state is almost absent and where the informal economy is the dominant industry. In these countries the black and gray markets are the most important factors of development stating that most of the added value is registered in cities[3]; the statistics are not conclusive for 
villages mostly due to household activities[4], as the tax system is not functioning properly. In transitional states and especially in former socialist states[2], the underground economy underwent a process of change and development. The change in structure has emerged from the opportunity of opening new markets, as well as from the surge in corruption phenomena, insufficient legislative regulations and proliferation of criminal structures.

Moreover, the possibilities to limit these phenomena come against the new circulation of capitals at a global level. More and more states base their economic growth on direct foreign investments. These investments sometimes favour transnational crime activities, because they do not have a national character and are difficult to monitor. It is known that, in reality, modern finances and the organized crime, aiming for profit, try to evade regulations and to suppress any form of control. Thus, money laundering methods have diversified from recycling money by the purchase of works of art or laundering through false lawsuits, to offshore accounts and tax havens. But, generally, at the basis of this type of activities lie the transfers via the global financial system using the newest technologies in the field.

\section{The money laundering process}

Generally, all activities within the scope of the underground economy phenomenon result in concealing gains from this process through various means of money laundering.

The phrase money whitening[5] comes from the U.S. during Prohibition, and remains widely used informally to this day. The method generally used was to deposit money in a bank that is not interested in their origin or to use drug money to buy luxury goods which are subsequently sold at a price that is lower than the buying price.

The first step in the money laundering process is to place money with financial banking institutions, as securities or to purchase high value items or to transfer them abroad.

The second step means going through a complex system of financial and commercial operations meant to hide the illicit origin of the money through successive transfers and sells, placements and investments.

The last step has as purpose creating the appearance of legality for these operations through false invoices or the transfer of amounts across several borders.

In general, the most used methods to hide the origin of dirty money are represented by:

1) False overcharge. The method implies an interloper selling false contemporary art works at a high price to an accomplice. The interloper receives, as payment for the sold objects, the amount he intended to launder, previously sent to the accomplice buyer. Later on, the accomplice returns the art works to their previous owner and cashes a commission.

2) False lawsuit. The money to be laundered is deposited illegally in the bank account of a Cayman Island company. Following a lawsuit filed by the money depositor against the Cayman Island company, the latter accepts to pay an amount equivalent to the one deposited in exchange for the drop of charges.

3) Layering. The money launderer sets up a bogus company in Lichtenstein, in the name of which opens a bank account in Vaduz. The money launderer phones the bank in Vaduz to launder a million dollars in cash. The bank sends him a courier, also a client of the bank. In Paris the courier receives the million dollars in cash from the one who wants to launder the money. Upon receipt he phones the bank in Vaduz to order the transfer of 800.000 dollars from his own account to the account of the bogus company.

4) Reverse money laundering. The Russian Mafia hijacks Siberian oil and sells it on the free market in Rotterdam for 40 million dollars. The money is deposited in a London bank account. The Russian mob, through a network of controlled banks gives a bank in New York an order to issue new dollar bills. London transfers 40 million dollars to the private New York bank. The New York bank buys from Federal Reserve new dollar bills totalling the amount of 40 million dollars. Federal Reserve delivers the new banknotes that are sent through the network of banks controlled by the mob to Moscow.

In Europe there are various methods to exploit the weak points of the single market. Thus, it is possible for a company to issue false export invoices through which VAT return can be obtained. Thanks to a system of false invoices VAT is charged for fictitious merchandise.

Another fraud mechanism is represented by the taxation of substantial subventions from the European Union for food products considered decayed, as well as embezzling the support money intended for tourism. The subventions constitute the only true profit of the operation.

\section{Combating money laundering globally}

At the basis of the money laundering phenomenon lies the development of new technologies, which results in an increased difficulty to discover the source of money transfers in the global financial system that links various financial institutions. Thus[6], within the network that includes The Society for Worldwide Interbank Financial Telecommunication (SWIFT), Federal Wire Transmission System (Fedwire), Clearinghouse Interbank Payments System (CHIPS), following the analysis of the Office of Technology Assessment U.S, allegedly between 0.05-0.1\% of the 700.000 daily transfers contain laundered funds that amount to 300 million dollars. In this mechanism are involved institutions like Bank of America, Bank of New York, Chase Manhattan, Swiss Bank Corporation, Deutschebank etc., the laundering taking place even if the existent regulations are observed.

This highly complex issue has been the object of many international organizations and non-governmental bodies. Their scope of activities includes actions for cooperation between countries, assistance with the legislative implementation and finding the best prevention methods, organizing working groups, supporting civil society, strengthening the legal regulations, advice, training and seminars. Money laundering is subject to the Commission on Crime Prevention and Criminal Justice (CCPCJ[7]), a United Nations' specialized structure, to the Financial Action Task Force on Money Laundering (FATF) which has compiled a blacklist of countries not cooperating in the fight against money laundering, followed by INTERPOL and EUROPOL.

FATF[8] (Financial Action Task Force on Money 
Laundering) was established during the G7 Summit in Paris in 1989, with the original purpose of combating laundering of money from drugs, and then of examining techniques and new trends in money laundering, developing specific measures to combat the phenomenon and overseeing respective actions both nationally and globally. The organization cooperates with regional organizations involved in combating money laundering such as the Caribbean Financial Action Task Force, The Eurasian Group on Combating Money Laundering, Asia Pacific Group on Money Laundering but also with international ones like regional development banks, IMF, World Bank, INTERPOL, EUROPOL, ECB or UNODC.

FATF, as an international organization, was created by the $\mathrm{G} 7$ with the purpose of examining and involving in the strategies of the fight against the phenomenon. The organization has drawn a list of the non-cooperative states in matters of money laundering limitation and has assessed this market to a value between 2 and $5 \%$ of the global GDP. It is believed that the main European banks located in countries deemed non-cooperative by the OECD are involved in the process.

FATF is considering the following strategic issues:

- the issue of international standards for combating money laundering and terrorist financing;

- $\quad$ creating a framework for global action against this phenomenon and ensure that its members implement the issued recommendations;

- developing relations between members, the regional organizations of the FATF (FSRBS), the Offshore group of Banking Supervisors (OGBS) and nonmember states;

- $\quad$ preparation of studies on money laundering typologies and informing the public on the importance of these phenomena.

Thus, the FATF has promulgated 40 Recommendations in order to set an applicable universal legal base for implementing anti-laundering programs at national scale, further completed with other 9 special recommendations on terrorism financing. In the case of recommendations regarding the legal system there is reference to the scope of the money laundering crimes (R1, R2) and to provisional measures and confiscation of the product of such crimes (R3). Hence the recommendation no. 1 states the fact that according to the Wien Convention pertaining to illicit drug traffic and the Palermo Convention against organized crime, the money laundering must be considered by the state members as a crime with certain gravity. Moreover, the second recommendation states that all evidence needed for incrimination must be obtained by observing the two conventions. The moment the money laundering crime is proved to have existed, according to the third recommendation, the countries must adopt the legislative measures to enable the special authorities to confiscate the proceeds of crime but without prejudicing the bona fidae of the third party beneficiaries. The measures to identify the goods or to seize them will be taken either without requiring a criminal conviction or, in some cases, with proof of crime.

About the recommendations regarding the control measures that must be taken by the fiscal institutions there is reference to due diligence and record keeping (R 4, R5, R6, R7, R8, R9, R10, R11, R12), suspicious transaction reporting (R13, R14, R15, R16), anti-money laundering procedures and countering the financing of terrorism (R17, $\mathrm{R} 18, \mathrm{R} 19, \mathrm{R} 20)$, the relation with the non compliant countries (R21, R22), norms regarding monitoring and supervising (R23, R24, R25). It is desired that the countries to ensure the fact that the existence of the confidentiality clause will not affect the implementation of the recommendations in the institutional framework. According to recommendation no. 5 financial institutions must obtain, verify and retain information concerning the identity of the account holder in case of occasional transactions or money laundering suspicions. Measures to obtain data about clients, beneficiaries or the nature of the business may be simplified or extended in case of risk. According to recommendation no. 10 financial institutions should maintain, for at least five years, all necessary records on transactions, both domestic or international, to inform the competent authorities at the same time paying attention to money laundering threats that may arise from new or developing technologies (R8). Recommendations no. 6, 7 and 9 refer to ways to verify the identity of the clients, to monitor the business relations, to establish the source of wealth and obtain senior management approval for opening new accounts, situations that can be covered together with correspondent banks internationally or by third parties. The transactions with no apparent economic or visible lawful purpose are also taken into consideration (R11), all these recommendations being applied to designated non-financial businesses or professions like casinos, real estate agencies, lawyers, accountants, public notaries etc. (R12). Any suspect activities will be reported to the specialized financial intelligence unit (FIU) (R13), the ones involved being protected by legal provisions from criminal and civil liability if they report their suspicions in good faith to the FIU (R14); financial institutions should continuously develop the internal policies, audit procedures (R15). According to recommendations no. 17, 18, 19 and 20, the states will impose legal measures on all persons that do not comply with these instruments, will encourage the development of new techniques to counter money laundering - among others should not approve the functioning of shell banks and will report all transactions over a certain threshold to specialized agencies. Even if the principles applicable to financial institutions mentioned above are also applied to branches located abroad (R22), special observance will be given to business relationships with companies and financial institutions from countries which do not or insufficiently apply the FATF Recommendations in which case appropriate countermeasures could apply. Recommendations no. 23 and 25 refer to preventing criminals or their associates from holding a management function in a financial institution, as well as assisting with applying measures to combat money laundering and terrorist financing.

Among institutional measures for combating money laundering and terrorist financing is the establishment of centres for receiving, analysing and disseminating information regarding these crimes (R26), the existence of 
competent authorities and special techniques of investigation like undercover operations or groups specialised in asset investigation (R27), as well as their possibility to obtain documents and evidence from other institutions sometimes using compulsory measures (R28). Competent authorities can impose administrative sanctions to institutions that do not comply with the requirements (R29), making sure that the law enforcers and supervisors are trustful and have effective mechanisms in place which enable them to implement activities to combat and cooperate (R31). Countries should take measures to prevent the unlawful use of legal persons for money laundering purposes (R33,R34), and the competent authorities will be able to review the effectiveness of their systems to combat money laundering on matters relevant to the effectiveness and efficiency of such systems (R32). Regarding cooperation the member states are encouraged to ratify the relevant international conventions of the Council of Europe Convention on Laundering, Search, Seizure and Confiscation of the Proceeds from Crime or the InterAmerican Convention against Terrorism (R35), along with the mutual legal assistance through competent authorities (R36), notwithstanding the absence of dual criminality (R37). Money laundering will be recognized as extraditable offence, or, where not possible, countries should cooperate with each other, in particular on procedural and evidentiary aspects, to ensure the efficiency of such prosecutions (R39), foreign countries being able, upon request, to identify, freeze, seize and confiscate property resulted from the crime, on the territory of another country (R38). Countries will ensure that the competent authorities will provide the widest possible range of international co-operation to their foreign counterparts facilitating the information exchange, conducting inquiries in their name and extending the cooperation to non-counterparts as well (R40).

INTERPOL[1], in respect of financial and high-tech crimes, are dealing with currency counterfeiting, money laundering, intellectual property crime, payment card fraud, computer virus attacks and cyber-terrorism. The organization tries to limit these phenomena by cooperating with software companies, central banks or other relevant entities.

Currency counterfeiting and money laundering are financial crimes with high impact according to EUROPOL also, especially due to the extent of the new technologies and increased professionals participation. The majority of counterfeit currency is produced in Southern and Eastern Europe, EUROPOL's activities consisting in offering operational support, analysis and expertise.

The organization has identified new directions in the organized crime activity such as:

- a growth in the organized crime activity at international level, corresponding to new activities and geographical areas;

- $\quad$ using legal businesses as a front to hide criminal activities;

- attracting professionals within organized crime groups;

- multiplication of cooperation between indigenous and foreign crime groups;
- $\quad$ increasing the number of crimes that offer a high profit, such as money laundering

In order to stop these phenomena EUROPOL cooperates both with member and non-member states and also with other similar international organizations. In this respect, we identify information exchanges or strategic cooperation with countries like Bulgaria, Norway, Iceland, and Romania but also with the European Central Bank, European Commission and OLAF.

In order to fight this phenomenon the action plan of the European Union has as principal objectives the strengthening of the regulation framework of 1999 regarding the activities and competences of the OLAF (amelioration of the information flow between the Office and the European Institutions), the amelioration of the information flow between the member states and the Committee (developing the Customs File Identification Database (FIDE)) and the development of the judicial protection of tax crimes.

The International Monetary Fund got involved with priority in combating money laundering after the September 11 attack. As criminal organizations were using the differences between national systems in combating this phenomenon, the organization has tried to impose international standards against these procedures, even when the amounts were transferred in tax havens. The IMF has provided technical assistance to states for tax policies, expenditure management, financial sector management and the issue of fiscal statistics, thereby facilitating the international exchange of information.

In turn, the World Bank has developed strategies to eradicate corruption, procedures that will be at the basis of all international banking operations. The implementation of this system by the Bank, through partnerships, will also consider cooperation with rich countries regarding the fight against transfers of money resulting from crime, in the accounts of foreign banks.

The national legislation framework. The Case of Romania

Fighting crime phenomena at national level was done by both decreeing locally specific regulation[9] and as a result of an international cooperation process.

As a preliminary measure in the formation of institutions combating this phenomenon, the association to commit crimes was regulated, then the phenomenon of organized crime was covered extensively[10], considering as its specific ways the embezzlement, human trafficking, money laundering, corruption, smuggling, fraudulent bankruptcy, etc. These can be done by an organized criminal group acting in a coordinated way to obtain material or financial benefits in the presence of a hierarchical pyramidal structure.

All these phenomena of the underground economy have continued to increase due to legal uncertainties, the society's attitude of acceptance regarding criminal acts, decentralization, and cooperation between groups existing in the socialist period and their correspondents in the international circuit.

Thus, fighting the phenomenon[11] was carried out at national level, through the Law 656/2002 on preventing and sanctioning money laundering. By law, money 
laundering[12] represents the changing and transfer of values with the purpose of concealing or disguising the illicit origin of goods from drug trafficking, failure to observe the arms and ammunition regime, pimping, smuggling, extortion, illegal detention, fraudulent bankruptcy, smuggling of weapons protected in their countries, trade in human organs and tissues, crimes committed by persons as part of associations of offenders or to help the person who committed the crime from which the goods derived, to evade prosecution, trial or execution of punishment.

Thus, are subject to law, under Article 8, banks, financial institutions (investment funds, investment companies, investment administration companies, depositary companies, custody companies, securities companies, pension funds and similar funds that perform the following operations: crediting, including, inter alia, consumer credit, mortgage credit, factoring, financing of commercial transactions, including forfeiting, financial leasing, payment operations, issuing and administration of payment means, credit cards, travellers checks and the like, granting or undertaking guarantees and underwriting commitments, trading for own account or for the account of customers using money market instruments, checks, payment orders, deposit certificates, etc., foreign exchange, derivatives, financial instruments related to foreign exchange rates or interest rates, securities, participation in the issuance of shares and providing services related to such issues, consultancy on matters of capital structure, industrial strategy, consultancy and services in mergers and acquisitions of enterprises, brokerage on inter-banking markets, portfolio administration and consultancy on portfolio administration, custody and administration of securities), insurance and reinsurance companies, operators engaged in gambling, pawning, trading of art objects, precious metals and stones, dealers, tourism operators, services providers and other similar activities involving movement of values, natural and legal persons providing legal, notary, accounting and banking professional assistance, notwithstanding their professional secrecy legal provisions, persons with attributions in the privatization process, post offices and legal persons providing money transmission services in lei or foreign currency, real estate agents, state treasury, foreign exchange offices and any other natural or legal person for acts and deeds committed outside the financial and banking system.

The law demands[12], by Article 3.(1) that as soon as the employee of a legal entity or one of the natural persons referred to in Article 8 has suspicions that a transaction, which is on the way to be performed, has the purpose of money laundering, he shall inform the person appointed who shall immediately notify the National Office for Preventing and Control of Money Laundering. The aforementioned persons will report to the Office, within 24 hours, any operations with cash, in lei or foreign currency, whose minimum is the equivalent in lei of 10,000 Euros, whether the transaction is carried out by one or more linked operations and will establish the identity of customers when initiating business relationships. But when there is an indication that the operation aims at money laundering, customer identification will proceed even if the transaction is less than the minimum established by law. If after processing the information received by the Office it finds that there is no indication of money laundering, the Office keeps the information on record for five years and then classifies it.

Persons referred to in Art. 8 and their employees and staff of the Office shall be required, not to convey information held in relation to money laundering and not to warn customers of formal complaints, otherwise being considered offenders punishable with imprisonment for 2-7 years.

Following the notification, the Office may order, on reasonable grounds, the suspension of the transaction for a period of 48 hours or may require, on reasonable grounds, before that date, the General Prosecutor's Office attached to the High Court of Cassation and Justice to extend the suspension of the operation with no more than 3 working days. The Prosecutor of the High Court of Cassation and Justice may authorize a one-time extension as requested or, if necessary, may terminate the suspension of the operation. The suspension decision will be communicated to the persons referred to in Art. 8 within 24 hours, otherwise the operation can be continued by them.

Banking secrecy and professional secrecy are not opposable to the prosecution, after the commencement of criminal prosecution by the prosecutor, or to courts. The prosecutor may order, when there are serious indications on the offense of money laundering, surveillance arrangements for a fixed term on bank accounts and similar accounts or access to their telecommunications systems or information systems, if there are indications that a person uses them in preparation of a crime.

In terms of what sanctions may be imposed by law[12], the following constitute the offense of money laundering and are punished with imprisonment from 3 to 12 years:

a) conversion or transfer of property, knowing that it is proceeds of crime, for the purpose of concealing or disguising the illicit origin of such property or of assisting the person who committed the crime from which the goods derived to evade prosecution, trial or execution of punishment;

b) the concealment or disguise of the true nature, source, location, disposition, movement, rights with respect to, or ownership of property, knowing that such property is derived from criminal activity;

c) the acquisition, possession or use of property, knowing that it is proceeds of crime.

Association to commit or initiation of an association, adhesion, or abetting in any kind of such an association for the purpose of committing the money laundering offence, shall be punished with 5 to 15 years of imprisonment.

For all these offenses, the attempt is punishable, and property from crime can be confiscated.

At the same time combating these phenomena was made by Law no.176/2010 [16]. Law took into account the obligation of certain categories of persons to file declarations of assets and interests. In the legal sense, the following persons had this obligation: the President of Romania, Presidents of both Chambers of Parliament, MPs and senators, Romania's members in the European 
Parliament, the Prime Minister, Cabinet members, state secretaries, judges, prosecutors, members of the Court, the director of the Romanian Intelligence Service, diplomatic and consular staff, persons responsible for management and control and public officials, board members who hold leadership positions in the autonomous public enterprises of national interest, staff of public institutions, trade union federation presidents, prefects and candidates for such functions.

The assessment of these statements is made by the National Integrity Agency. It monitors the data and takes attitude in case of an incompatibility with their positions or in case of conflicts of interest. Agency's goal is to ensure integrity in the exercise of public dignities, and may order the person in a conflict of interest or incompatibility to be released or dismissed from office. This person will be deprived of its right to exercise that function or dignity for a period of three years from the date of dismissal. The sanctioned person may appeal the decision of the Agency in the administrative court. Also failure to submit these statements within the required time constitutes an offense and is punishable by fine.

These statements will be made public on the website of the institution employing the persons submitting the statements of assets or interests and are maintained for a period of 3 years after leaving office.

However, the existence of these regulations has not removed some of the old socialist regime practices like corruption or bribery, which made the underground economy in Romania to continually increase after 1990, in a free market economy system, particularly because[13]:

- tax legislation is inconsistent and presents multiple gaps;

- decentralization increased the opportunities for corruption;

- there is a generalized attitude of acceptance of corruption[14] from the public and the authorities;

- the existence of a parallel economy inherited from the old regime;

- $\quad$ the economic restructuring led to the emergence of small businesses, generating significant underground economy;

- a large number of normative acts[15] in tax legislation and frequent changes occurred in legislation or even overlaps (the law on tax evasion and money laundering emerged too late);

- $\quad$ the continued growth of the tax burden on taxpayers and the lack of specialists in the field of taxation.

\section{CONCLUSION}

The globalization and regionalization have created an important issue for the international community, in that criminal groups have come to meet these challenges by organizing international networks in order to manage their own activity with increased efficiency and mainly using sophisticated technological means and exploiting the free borders. New communications systems and advanced technology have reduced the distances between countries, have opened borders and created unimaginable opportunities for political or social interactions, but also for the expansion of phenomena in direct connection with the underground economy.

Globalization has allowed a qualitative leap of critical importance for the business of transnational organized crime groups, providing them not only an ideal environment for business development, but also ways of obtaining illegal goods or some of their manufacturing processes. Welfare gained by opening borders to trade flows is counterbalanced by the threat to human security.

The economist Alain Cotta noted in the '80s an unprecedented development of corruption by the appearance of three new vectors namely drug money that needed to be laundered, political party financing and decentralization. In the case of parties, the political systems have resorted to new solutions to simplify the compromise, like offices of education, false billing methods or public procurement system and permits.

Although money laundering market was valued at \$600 billion, i.e. between 2 and $5 \%$ of global GDP, the new movement of capital boosts the activity of transnational crime whose lack in national character hinders the possibilities of repression. Modern finance and organized crime pursue common objectives, namely the abolition of regulations and removing state control; banking secrecy, swaps, offshore accounts, tax havens, all are underlying such transactions. There are also less elaborate money laundering methods such as recycling of money through the purchase of works of art, challenging transactions through fake trials and laundering through money carriers that smuggle various amounts over borders.

In this case, the fight against the money laundering process requires specific national regulations which must be integrated in the international cooperation process.

At the same time there is a need to implement an attitude of non-acceptance of such phenomena at the level of civil society, in terms of a better informed public opinion concerning these aspects.

\section{BIBLIOGRAPHY}

[1] D.Rădulescu, Probleme globale contemporane, Universitatea PetrolGaze ed., Ploiești, 2007, pp.13;

[2] F.Schneider, D.H.Enste, The Shadow Economy, An International Survey, University Press, Cambridge, 2005;

[3] I. Rădulescu I., Dualismul economiei mondiale, Universitatea PetrolGaze ed., Ploieşti, 2007, pp.9;

[4] J. Cazenave., Economie en sous-sol, INSEE Antiane, No.23 Decembre 93;

[5] M. Debare M., Les milliards de l'ombre l'économie souterraine, Hatier ed., Paris, 1992,pp.7-30 ;

[6] Bişa C., Costea I., Capotă M., Dăncău B., Utilizarea paradisurilor fiscale, BMT Publishing House ed., Bucureşti, 2005, pp.5-25;

[7] www.un.org;

[8] www.fatf-gafi.org;

[9] D. Miclea, Combaterea crimei organizate, Ministerul Administrației şi Internelor ed., Bucureşti, 2004, pp.100-150;

[10] Law no. 39/2003 regarding the combating of organized crime, published in The Official Gazette of Romania no.50 of 29 Jan. 2003;

[11] E. Tanislav, N.Cornea, E.Tanislav.jr., Infracţiuni prevăzute în legi speciale, Semne ed., Bucureşti, 2006, pp.849;

[12] Law no. 656/2002 regarding the prevention and sanctioning of money laundering, published in OG no.904/12.12.2002;

[13] N.Craiu, Economia subterană în România, Revista de finanțe publice şi contabilitate nr.1112, Bucureşti, 2003 ; 
[14] S.Popa, N.Craiu, A.Cucu, Economia subterană şi spălarea banilor, Expert ed., Bucureşti, 2000, pp.15-34;

[15] Curtea de Conturi a României, Nivelul şi evoluţia economiei subterane în România, Economistul nr.1787, 2005.

[16] Law no.176/2010 regarding integrity in exercising public functions and dignities 